\title{
Influence of In-sourcing and Outsourcing of Consultants on Construction Project Performance in Nigeria
}

Godwin Iroroakpo Idoro, (University of Lagos, Nigeria)

\begin{abstract}
Research studies have discovered that outsourcing has several benefits and the practice is fast replacing in-sourcing especially with regard to construction consultants. In the attempt to examine the benefits of the two approaches on project outcome, this study investigates the influence of the use of in-sourced and outsourced consultants on project performance in Nigeria. The objectives are to determine the use of in-sourcing and outsourcing for selected consultants, compare the use of the two approaches in project delivery and their influence on project performance and compare the performance of projects in which in-sourced and outsourced selected consultants were engaged. To achieve these objectives, a questionnaire design approach was adopted. A field survey involving a sample of 164 projects were selected by stratified random sampling. Data were collected using structured questionnaires and analysed using percentage, mean, Spearman and t-tests. The results of the study reveal that clients engage both in-sourced and outsourced consultants in project development and that the practice has significant influence on project performance. It also discovered that the use of the two approaches has differing benefits on project delivery time and cost. The study concludes that in-sourcing and outsourcing are common practices in project development and that clients are facing a challenge in deciding which approach to adopt. The study also discovers that both approaches has benefits associated with project outcome and suggests that clients should consider these benefits in their decision to in-source or outsource consultants.
\end{abstract}

Keywords: Construction projects, In-sourced consultants, Nigeria, Outsourced consultants and Project performance

\section{Introduction}

The importance of consultants in construction project delivery cannot be over-emphasised. Consultants as Havemann (2007) put it are accountable for the technical risks in a conventional project. They are responsible for developing the requirements of project clients, setting targets, deadlines and establishing standards for meeting these requirements, preparing project documents that describe the targets, deadlines and standards set and sometimes monitoring the activities of contractors that execute a project to ensure that the targets, deadlines and standards are achieved. It suffices to say that a project cannot be successfully executed without the services of consultants.

These consultants are engaged from two sources namely: in-house or external. In-house consultants can otherwise be described as internal service providers or in-sourced consultants. These refer to professionals on permanent employment of the client who are engaged to perform the services of consultants in the procurement of a project. Outsourced consultants can otherwise be described as external or outsourced service providers. These refer to professionals who operate consultancy outfits that are engaged by a client to provide specialised services in the course of procuring a project. Traditionally, organisations used to engage professionals on permanent employment to perform the services of consultants. 
However, in the past decade, outsourcing has become a prevalent practice in most countries. Sattineni and University (2008) opined that in developing countries, white collar jobs that were hitherto considered to be stable are now being outsourced.

The main concern about consultants that prompts this study is that most of the major clients in particular the public and organised private sector clients have departments where professionals are employed. These professionals are often responsible for most pre-design services and they are fully involved in both design and construction activities. In organisations where project delivery is fully internalised, in-sourced consultants perform all the activities relating to design and construction of a project. Idoro (2006) described the in-house project delivery process as direct labour approach. In other projects, clients use in-sourced consultants for some services while engaging external consultants for others. In projects where outsourced consultants are involved, client's professional staff serve as intermediaries between the external consultants and the client who often seek their advice on every matter relating to a project. Boes and Doree (2009) opined that the preparatory activities in traditional contract are either carried out in-house or outsourced to consulting engineering firms and that outsourcing to consulting engineering firms requires in-house control measures. They maintained that reducing staff by outsourcing tasks to engineering consultants creates new issues of quality control, risks and staffing. The main questions raised by this practice are: what is the preference of construction clients on inhouse and outsourced consultants in project delivery? What is the effect of in-house and outsourced consultants on project performance? The problem of the study therefore is to determine the influence of in-sourced and outsourced consultants on project performance. The objectives are to compare the extent of use of in-sourced and outsourced project consultants in project delivery and the effect of their use on project performance. The achievement of these objectives will assist stakeholders in the industry in their decision on whether to engage insourced or outsourced consultants in project development.

\section{Hypotheses of the Study}

In the attempt to achieve the objectives of the study, three hypotheses were postulated. The first hypothesis states that the extent of use of in-sourced and outsourced consultants in project development is not significantly different. This hypothesis is tested to establish the preference of clients on the two types of consultants. The second hypothesis states that the extent of use of in-sourced and outsourced consultants has no significant relationship with project performance. The test of this hypothesis is expected to assist clients to know the influence of the use of insourced and outsourced consultants on project performance. The third hypothesis states that the outcome of projects in which in-sourced consultants were engaged is not significantly different from the outcome of projects in which outsourced consultants were engaged. The results of the hypothesis are expected to assist clients to know the effect of engaging the two types of consultants and which consultants to source in-house or outside

\section{Conceptual Framework of the Study}

Three categories of variables namely: project consultant, consultant source and project performance were used in the study. Six project consultants namely: project manager, architect, quantity surveyor, structural, electrical and mechanical engineers were used. Consultant source was classified into in-source and outsource while twelve variables namely: respondents' assessment of project cost, duration, quality, variations, fluctuation, risks, conflicts between client and contractors, conflicts between client and consultants, conflicts between consultants and contractors, compliance with contract obligations, time-overrun and cost-overrun were used as parameters of project performance. The last two parameters of project performance were used as parameters of project outcome because the effects of the other ten parameters are expected to manifest in them. Project success which is reflected in project performance is the

Idoro, G I (2011) 'Influence in-sourcing and outsourcing of consultants on construction project performance in Nigeria', Australasian Journal of Construction Economics and Building, 11 (4) 45-58 
purpose of engaging consultants. Hence, the relationship between the two types of consultants and project performance and the difference in the outcome of projects in which in-sourced and outsourced consultants were engaged were used to determine the benefits in project performance of the two types of consultants. This relationship is expressed in Fig.1.

\begin{tabular}{|c|c|c|}
\hline Project consultant & & Project performance \\
\hline \multirow{2}{*}{$\begin{array}{l}\text { 1. Project manager } \\
\text { 2. Architect } \\
\text { 3. Structural engineer } \\
\text { 4. Quantity surveyor } \\
\text { 5. Electrical engineer } \\
\text { 6. Mechanical }\end{array}$} & $\begin{array}{l}\text { Consultant } \\
\text { source }\end{array}$ & \multirow{3}{*}{$\begin{array}{l}\text { Consultants' assessment of } \\
\text { 1. Project time } \\
\text { 2. Project cost } \\
\text { 3. Project quality } \\
\text { 4. Variations } \\
\text { 5. Fluctuation } \\
\text { 6. Project risks } \\
\text { 7. Conflict between client \& contractors } \\
\text { 8. Conflict between client \& consultants } \\
\text { 9. Conflict between consultants \& contractors } \\
\text { 10. Compliance with contract obligations } \\
\text { Project outcome } \\
\text { 11. Time-overrun } \\
\text { 12. Cost-overrun }\end{array}$} \\
\hline & $\begin{array}{l}\text { 1. In-source } \\
\text { 2. Outsource }\end{array}$ & \\
\hline \multicolumn{2}{|c|}{$\begin{array}{l}\text { Figure } 1 \text { Framework for evaluating the relationship } \\
\text { between the use of in-sourced and outsourced } \\
\text { consultants and project performance }\end{array}$} & \\
\hline
\end{tabular}

\section{Previous Studies}

The construction industry is one of the most important economic sectors in Nigeria. The industry is known to account for a major proportion of the Gross Domestic Product (GDP) of Nigeria (Federal Government of Nigeria, 1986; Idoro, 2004). The industry is also a major contributor to employment generation by providing employment to millions of people in diverse professions and skills as well as serving as a vocational training ground. There are several parties that are involved in the delivery of construction projects. Idoro (2009a) stated that project teams consist of many parties who have several responsibilities to perform in order to ensure the success of a project. He identified the notable parties as clients, consultants, contractors, suppliers and manufacturers. Clients in the Nigerian construction industry are classified into two categories namely: public clients made up of the federal, state and local governments and their respective parastatals and private clients made up of individuals and corporate organisations. Idoro and Okun (2011) opined that in Nigeria, government is the main promoter of construction projects and that the private sector depends to a considerable on government expenditure. Nigerian contractors are often categorised as either indigenous that is construction firms that are fully owned and managed by Nigerians or expatriates that is those firms that are jointly owned by Nigerians and foreigners but solely managed by expatriates (Idoro, 2009b). Olateju (1991) reported that indigenous contractors were responsible for only $7 \%$ of the total value of contracts awarded from 1974 to 1994 while their expatriate counterparts were responsible for the remaining 93\%. In a study that investigated the reasons for the poor participation of indigenous contractors in contracts' execution, Idoro (2010) discovered that Nigerian clients perceive the quality performance of expatriate contractors to be better than that of indigenous contractors and confirmed that clients indeed give preference to expatriate contractors in the award of contracts.

There are many professionals that are involved in the design and construction of projects in Nigeria that are regarded as consultants. In a study of quantity surveying practice in Nigeria, Odusami (1999) stated that in Nigeria as in Britain, the quantity surveyor is one of the key professionals involved in the design and execution of construction projects. Others include architects and structural, electrical and mechanical engineers. These consultants can either be 
outsourced through direct employment by client, nomination by architect/project manager, nomination by other consultants or competitive bidding from professionals operating consultancy outfits outside the client organisation or in-sourced from professionals that are within the client organisation (Odusami, 1999).

In the attempt to examine the application of outsourcing in different areas of organisations' activities, researchers describe it in various ways: the significant contribution by external vendors in the physical and human resources associated with the entire or specific components of the IT infrastructure in the user organisation (Loh and Venkatraman, 1992); the extent of components and finished products supplied to a firm by independent suppliers (Kotabe, 1992); the reliance on external sources for the manufacturing of components and other value-adding activities (Lei and Hitt,1995). Grover et al. (1996) described outsourcing as the practice of turning over part or all of an organisation's internal functions to external service providers. Gilley and Rasheed (2000) felt that the term outsourcing is so wide that it covers virtually any good or service that an organisation procures from outside firms. Referring to another way outsourcing is practised in many organisations, Domberger (1998) believed that outsourcing is synonymous with contracting and therefore described it as the process of searching for and appointing contractors for the provision of goods and services and the execution of the contractual relations needed to support such activities. In another view, Ender and Mooney (1994) described outsourcing as a form of privatisation that refers to an organisation's (University) decision to contract with an external organisation to provide a traditional organisation function or service to the organisation.

All these descriptions (supply, externalisation, contracting and privatisation) show that outsourcing is practised in various ways in different organisations. While all of them can be said to convey the same meaning or practice, two of them mentioned another point to ponder about in outsourcing. Grover et al., (1996) called it 'internal functions' while Ender and Mooney (1994) regarded it as 'traditional functions'. The point in these definitions is that the products or services to be outsourced should be the ones that the organisation is or can currently produce or render. This view is supported by Gilley and Rasheed (2000) who argued that outsourcing may arise in two ways namely: 1) substitution of external purchases for internal activities that is discontinuation of goods or services and an initiation of procurement from outside suppliers and 2) abstention that is purchases of goods or services from outside organisations even when those goods or services have not been produced in-house in the past. The duo regarded outsourcing as a decision to reject internalisation that is in-house production of goods or services outsourced and opined that outsourcing occurs when the internalisation of the good or service outsourced is within the acquiring firm's managerial and/or financial capabilities. They suggested that organisations that have no choice but to acquire a particular good or service from external source because of lack of capital or expertise are not outsourcing because the internalisation of the activity in question is not an option. This view tends to indicate that outsourcing applies when the option of in-sourcing is available and that organisations are always faced with the decision on whether to adopt in-sourcing or outsourcing for their products or services.

This problem which clients have to confront when embarking on project development is the thrust of this study. Kanji and Wong (1998) maintained that the construction industry comprised of a multitude of occupations, professions and organisations that are involved in different phases of a construction project and consultants in collaboration with clients, contractors and sub-contractors all have a role to play in delivering a quality project. Renier and Volker (2009) maintained that every project is usually assigned a new team, precisely from a client's own network in which context social aspects play an important part. If a firm cannot draw from its 
own organisation structural engineers, building consultants, climate advisors, other external professionals have to be involved in the process as soon as possible. Meiling and Johnson (2009) opined that during design, manufacturing and erection, the building is thoroughly defined, manufactured and erected. Most of the activities remain in-house while some are performed by external consultants. The duo maintained further that in industrialised buildings in Sweden, drafting of the building envelope is handled by companies themselves while HVAC drafting, structural design, electrical drafting and life-cycle costing are done by external consultants. Although Sattineni and University (2008) regarded pre-construction, conception, design and tendering services as areas that suite outsourcing, however if contracting and privatisation are forms of outsourcing, it all means that construction activities are equally being outsourced in project delivery. The point in the above studies is that outsourcing whether full or partial is inevitable in the development of most construction projects.

The question that arises from the above review is if outsourcing is a feature of construction project development, what are the benefits derived from it? Research studies have discovered that organisations derive numerous benefits when they engage external service providers. It was discovered that by outsourcing, firms often achieve cost advantages relative to vertically integrated firms (Quinn 1992; Bettis, et al., 1992; D'Aveni and Ravenscraft, 1994; Lei and Hitt, 1995); manufacturing costs decline and investment in plant and equipment can be reduced (Bettis et al., 1992); reduced fixed costs that leads to a lower break-even point (Gilley and Rasheed, 2000); firms have opportunities for flexibility in technology (Harrigan, 1985); economies of scale by increasing net value and reducing costs, process expertise, access to capital and expensive technology, greater capacity for flexibility (Carlson, 1989; Harrison, 1994); enhanced competitiveness (Gilley and Rasheed, 2000); quick response to environmental changes (Dess et al., 1995); increased management attention and resource allocation to those tasks that an organisation does best and reliance on management teams in other organisations to oversee tasks in which the outsourcing firm is at relative advantage (Quinn et al., 1990); emerging technology without significant investment in the technology (Gilley and Rasheed, 2000); focus on core competencies (Kotabe and Murray, 1990; Quinn, 1992; Dess et al., 1995; Sang, 2010). While previous studies have covered many benefits in outsourcing, the aspect of project performance has been virtually neglected. The benefits that a client will derive in terms of the outcome of projects which is the focus of this study are not in the studies.

Despite these numerous benefits, several problems have been observed on the use of external consultants. Outsourcing can lead to loss of overall market performance (Bettis et al., 1992; Kotabe, 1992) or less investment in research and development which may lead to decline in innovation (Teece, 1987). In a project that involved a change of client, Michell et al., (2007) discovered problems concerning cooperation between consultants and contractors. As a solution to the problem of inaccurate proposals submitted by consultants, Tembo and Rwelamila (2007) suggested that organisations should formulate an evaluation process for the assessment of project proposals from consultants in a manner that will reflect true costs and schedules. These problems show that the practice of outsourcing products or services by an organisation is not without losses.

\section{Research Methods}

A questionnaire survey approach was adopted for the study and a field survey involving 164 clients was conducted. A list of 211 organisations made up of 56 government and 155 organised private establishments was prepared through a preliminary survey conducted in the first quarter of 2010 because a reliable list or statistics of organisations involved in project development could not be obtained. These organisations were used as the population frame for the study. The study sample was selected from this population by stratified random sampling. In

Idoro, G I (2011) 'Influence in-sourcing and outsourcing of consultants on construction project performance in Nigeria', Australasian Journal of Construction Economics and Building, 11 (4) 45-58 
the sampling, the population was classified into public and private organisations thereafter; the respondents were selected from each sector randomly. One project preferably the one with the highest contract sum executed by each of the sampled organisations was selected to ensure that the consultants selected for the study were required in the project.

Data were collected on the characteristics of the projects sampled, the sources of six consultants discovered to be common to all the projects sampled, respondents' assessment of project duration, cost, quality, extent of risks, variations, fluctuation, compliance with contract obligations and conflicts and disagreement between client and contractors, client and consultants and contractors and consultants of the projects using five ranks namely: poor, low, moderate, high and very high. The ranks were assigned scores of 1,2, 3, 4 and 5 respectively. Data on the initial and actual duration and cost of the projects were also collected. The data were collected using structured questionnaires. The instrument was administered to the respondents by hand through personal visits paid to the organisations sampled in mid 2010 and completed questionnaires were also collected through the same approach. The extent of use of the two categories of consultants investigated was defined as the percentage of the six selected consultants engaged in-house or outsourced to procure the projects sampled. Time-overrun was defined as the percentage of the difference between actual and initial contract periods divided by initial contract period while cost-overrun was defined as the percentage of the difference between actual and initial contract sums divided by initial contract sum. The data were analysed using percentage, mean, t-test, Chi-square and Spearman correlation tests.

\section{Results of Data Analysis}

The results of the analysis of the data collected for the study are presented as follows.

\section{Characteristics of Projects used for the Study}

The characteristics of the projects used for the study were investigated for the purpose of understanding the projects which the results of the study apply to. Five project characteristics and their sub-types stated Table 1 were investigated. The percentages of each sub-type of project characteristics were analyzed. The results are presented in Table 1.

Table 1 shows that the projects sampled were procured by four notable methods namely: direct labour, traditional contract, design-build and labour-only however the percentage of projects procured by direct labour method was the highest. On the owners of the projects used for the study, Table 1 shows that both government and private sector projects procured were covered in the sample but private sector projects constituted the majority. On the type of construction, Table 1 shows that both new construction and renovation/maintenance works were sampled but the majority of the projects were new projects. Table 1 shows that projects were procured by the construction management method in which the construction manager is the coordinator, the project management system in which the project manager was the project leader and the traditional management method in which the architect was the project leader were sampled.

The analysis of the rise of the buildings sampled shows that low-rise (1-3 floors), medium-rise (4-7 floors) and high-rise (above 7 floors) buildings were covered but the majority of the projects were low-rise buildings. The analysis of the value of the projects shows that the five value intervals selected were covered in the projects sampled which indicates that the projects sampled were both small and large. On the duration of the projects sampled, Table 1 shows that the percentage of long duration (above 52 weeks) projects is the highest while the percentage of medium duration (26-52 weeks) projects is the lowest. On the contractor type that executed the projects sampled, Table 1 shows that projects executed by both indigenous and expatriate contractors in Nigeria were covered however, majority were executed by indigenous 
contractors. The analysis of the use of the buildings sampled shows that the projects covered by the study have several uses.

\begin{tabular}{|c|c|c|c|c|c|c|c|}
\hline Characteristic & Sub-type & $\mathbf{N}$ & $\%$ & Characteristic & Sub-type & $\mathbf{N}$ & $\%$ \\
\hline $\begin{array}{l}\text { Procurement } \\
\text { method }\end{array}$ & $\begin{array}{l}\text { Design-Bid-Build } \\
\text { Direct labour } \\
\text { Design-build } \\
\text { Labour-only } \\
\text { Total }\end{array}$ & $\begin{array}{r}42 \\
64 \\
42 \\
16 \\
164\end{array}$ & $\begin{array}{r}25.6 \\
39.0 \\
25.6 \\
9.0 \\
100\end{array}$ & Project value & $\begin{array}{l}\text { N 1- } 25 \text { million } \\
\text { N26-50 million } \\
\text { N51-75 million } \\
\text { N76-100million } \\
\text { Above N100 million } \\
\text { Total }\end{array}$ & $\begin{array}{r}32 \\
22 \\
26 \\
8 \\
28 \\
116\end{array}$ & $\begin{array}{r}27.6 \\
19.0 \\
22.4 \\
6.9 \\
24.1 \\
100\end{array}$ \\
\hline Client type & $\begin{array}{l}\text { Public } \\
\text { Private } \\
\text { Total }\end{array}$ & $\begin{array}{r}28 \\
136 \\
164\end{array}$ & $\begin{array}{r}17.1 \\
82.9 \\
100\end{array}$ & $\begin{array}{l}\text { Project } \\
\text { duration }\end{array}$ & $\begin{array}{l}1-26 \text { weeks } \\
27-52 \text { weeks } \\
\text { Above } 52 \text { weeks } \\
\text { Total }\end{array}$ & $\begin{array}{r}48 \\
40 \\
74 \\
162\end{array}$ & $\begin{array}{r}29.6 \\
24.7 \\
45.7 \\
100\end{array}$ \\
\hline $\begin{array}{l}\text { Construction } \\
\text { type }\end{array}$ & $\begin{array}{l}\text { New construction } \\
\text { Renovation } \\
\text { Total }\end{array}$ & $\begin{array}{r}122 \\
42 \\
164\end{array}$ & $\begin{array}{r}74.4 \\
25.6 \\
100\end{array}$ & $\begin{array}{l}\text { Contractor } \\
\text { type }\end{array}$ & $\begin{array}{l}\text { Expatriate } \\
\text { Indigenous } \\
\text { Total }\end{array}$ & $\begin{array}{r}42 \\
122 \\
164\end{array}$ & $\begin{array}{r}25.6 \\
74.6 \\
100\end{array}$ \\
\hline $\begin{array}{l}\text { Management } \\
\text { method }\end{array}$ & $\begin{array}{l}\text { Traditional } \\
\text { Project mgt } \\
\text { Construction mgt } \\
\text { Total }\end{array}$ & $\begin{array}{r}42 \\
58 \\
64 \\
164\end{array}$ & $\begin{array}{r}25.6 \\
35.4 \\
39.0 \\
100\end{array}$ & Project use & $\begin{array}{l}\text { Residential } \\
\text { Commercial } \\
\text { Industrial } \\
\text { Social } \\
\text { Total }\end{array}$ & $\begin{array}{r}88 \\
62 \\
2 \\
12 \\
164\end{array}$ & $\begin{array}{r}53.7 \\
37.8 \\
1.2 \\
7.3 \\
100\end{array}$ \\
\hline Building rise & $\begin{array}{l}1-3 \text { floors } \\
4-7 \text { floors } \\
\text { Above } 7 \text { floors } \\
\text { Total }\end{array}$ & $\begin{array}{r}96 \\
6 \\
22 \\
124\end{array}$ & $\begin{array}{r}77.4 \\
4.8 \\
17.7 \\
100\end{array}$ & & & & \\
\hline
\end{tabular}

Table 1 Descriptive result of characteristics of projects used for the study

$\mathrm{N}=$ Number of respondents. $\mathrm{N}=$ Naira (Nigerian official currency; $1 \mathrm{US} \$=158 \mathrm{~N}$ ), mgt=management

\section{Priority Accorded the Use of In-sourced and Outsourced Consultants}

To investigate the priority accorded the use of in-sourced and out-sourced consultants in project development, the percentages of the consultants in-sourced and outsourced were analysed and ranked separately. The results are presented in Table 2.

\begin{tabular}{|l|c|ccc|ccc|}
\hline \multicolumn{1}{|c|}{ Consultant } & Total & \multicolumn{3}{c|}{ In-source } & \multicolumn{3}{c|}{ Outsource } \\
& N & N & $\%$ & Rank & N & Rank \\
\hline Electrical engineer & 94 & 43 & 45.7 & 6 & 51 & 54.3 & 1 \\
Mechanical engineer & 90 & 46 & 51.1 & 5 & 44 & 48.9 & 2 \\
Architect & 98 & 55 & 56.1 & 4 & 43 & 43.9 & 3 \\
Structural engineer & 112 & 63 & 56.3 & 3 & 49 & 43.7 & 4 \\
Quantity surveyor & 108 & 68 & 63.0 & 2 & 40 & 37.0 & 5 \\
Project manager & 102 & 77 & 75.5 & 1 & 25 & 24.5 & 6 \\
\hline
\end{tabular}

Table 2 Ranks of the sources of selected project consultants

$\mathrm{N}=$ Number of respondents

Table 2 shows that the percentage of in-sourced project managers (75.5) ranked first while that of quantity surveyors (63) ranked second. The percentage of in-sourced structural engineers (56.3) ranked third while those of architects (56.1), mechanical engineers (51.1) and electrical engineers (45.7) ranked fourth, fifth and sixth respectively. 


\section{Test of Difference between the Use of In-sourced and Outsourced Consultants}

To test whether or not there is difference in the preference of the respondents for in-sourced and outsourced consultants, the first hypothesis was postulated. The hypothesis states that the extents of use of in-sourced and outsourced consultants in project development are not significantly different. The hypothesis was tested using the t-test with $p \leq 0.05$. The rule for the acceptance or rejection of the hypothesis is that when p-value $>0.05$, the hypothesis is accepted but when $p$-value $\leq 0.05$, the hypothesis is rejected. The results are presented in Table 3.

\begin{tabular}{|c|c|c|c|c|c|c|c|}
\hline \multicolumn{1}{|c|}{ Variables compared } & N & Mean & t-value & Df & p-value & Decision & Diff \\
\hline \% of in-sourced consultants & 164 & 50.27 & 0.158 & 158 & 0.874 & Accept & NS \\
\% of outsourced consultants & 164 & 49.73 & & & & & \\
\hline
\end{tabular}

Table 3 Results of t-test for difference between the use of in and out sourced consultants $\mathrm{N}=$ Number of respondents, $\mathrm{Df}=$ Degrees of freedom. Diff=Difference, NS=Not significant

Table 4 shows that the p-value (0.874) for the test of difference in the extent of use of insourced and outsourced consultants is greater than the critical p-value $(0.05)$ therefore the hypothesis is accepted. This result implies that the extent of use of in-sourced consultants is not significantly different from the extent of use of outsourced consultants. The result implies that clients have no preference for in-sourced or outsourced consultants in project development.

\section{Relationship between the Use of In-sourced and Outsourced Consultants and Project Performance}

To determine the influence of the use of the two types of consultants on project performance, the second hypothesis of the study was postulated. The hypothesis states that the extent of use of in-sourced and outsourced consultants and project performance are not significantly related that is the extent of use of either in-sourced or outsourced consultants does not have significant influence on project performance. For the test of the hypothesis, data collected on the use of the two variables of project consultants and the respondents' assessment of the twelve variables of project performance as stated in the research methods were used. The hypothesis was tested using the Chi-square and Spearman correlation tests with $p \leq 0.05$. The rule for the acceptance or rejection of the hypothesis is that when $p$-value $>0.05$, the hypothesis is accepted but when $p$ value $\leq 0.05$, the hypothesis is rejected. The results are presented in Table 4.

On the relationship between the use of in-sourced consultants and project performance, Table 4 shows that the $p$-values for the test of relationship between the percentage of in-sourced consultants and the respondents assessment of project duration (0.758), variations (0.663), fluctuation (0.229), project risks (0.097), conflicts/disagreement between consultants and contractors (0.356) and percentage of time-overrun to initial contract period $(0.080)$ are greater than the critical p-value (0.05) therefore the hypothesis is accepted. This result implies that the number of in-sourced project consultants has no significant relationship with the perception of clients on project duration, variations, fluctuation, project risks, conflicts or disagreements between consultants and contractors and the percentage of time-overrun to initial contract period of projects. However, the p-values for the test of correlation between the percentage of in-sourced consultants and the respondents' assessment of project cost (0.033), project quality (0.017), conflicts between clients and contractors (0.015), conflicts between clients and consultants $(0.038)$, compliance with contract obligations $(0.001)$ and percentage of costoverrun to initial contract period (0.002) are lower than the critical p-value $(0.05)$ therefore the hypothesis is rejected. The result indicates that the number of project consultants sourced from among clients' staff has significant correlation with the perception of the clients on project cost

Idoro, G I (2011) 'Influence in-sourcing and outsourcing of consultants on construction project performance in Nigeria', Australasian Journal of Construction Economics and Building, 11 (4) 45-58 
and quality, conflicts between clients and contractors and between client and consultants, compliance with contract obligations and overrun in the cost of projects.

\begin{tabular}{|l|c|c|c|c|c|}
\hline \multicolumn{1}{|c|}{ Variables correlated } & N & & p & Decision & Rel \\
\hline \% of in-sourced consultants & & $x^{2}$ & & & \\
Res asmt of project cost & 164 & 0.166 & 0.033 & Reject & S \\
Res asmt of project duration & 164 & -0.024 & 0.758 & Accept & NS \\
Res asmt of project quality & 164 & -0.186 & 0.017 & Reject & S \\
Res asmt of variations & 164 & -0.034 & 0.663 & Accept & NS \\
Res asmt of fluctuation & 164 & 0.095 & 0.229 & Accept & NS \\
Res asmt of project risk & 164 & 0.130 & 0.097 & Accept & NS \\
Res asmt of client \& contractors' conflicts & 164 & 0.189 & 0.015 & Reject & S \\
Res asmt of client \& consultants' conflicts & 164 & -0.162 & 0.038 & Reject & S \\
Res asmt of consultants \& contractors' conflicts & 164 & 0.072 & 0.356 & Accept & NS \\
Res asmt of compliance with contract obligations & 164 & 0.299 & 0.001 & Reject & S \\
& & $R$ & & & \\
\% time-overrun to initial contract period & 80 & 0.197 & 0.80 & Accept & NS \\
\% cost-overrun to initial contract sum & 54 & -0.409 & 0.002 & Reject & S \\
\hline
\end{tabular}

Table 4 Results of Spearman test of correlation between the use of in-sourced and outsourced consultants and project performance

$\mathrm{N}=$ Number of respondents, $x^{2}=$ Chi-square value, $\mathrm{R}=$ Correlation coefficient, $p=p$-value, Res=respondent, Asmt=assessment, Rel=relationship, $\mathrm{S}=$ significant, NS=not significant

\section{Difference between Performance of Projects based on the Use of In-sourced and Outsourced Consultants}

The argument in favour of the use of outsourced consultants has been that the cost is less than that of engaging in-sourced consultants. The attempt to justify the engagement of in-sourced consultants prompts the comparison between the performance of projects in which in-sourced consultants were engaged with that of projects in which outsourced consultants were engaged. For the purpose of this comparison, the percentages of time-overrun to initial contract period and cost-overrun to initial contract sum of projects in which in-sourced project managers, architects, quantity surveyors and structural, electrical and mechanical engineers were engaged were compared with those of projects in which outsourced consultants were engaged. The third hypothesis of the study was postulated for purpose of the comparison. The hypothesis states that the performance of projects in which in-sourced consultants were engaged is not significantly different from the performance of projects in which outsourced consultants were engaged. The hypothesis was tested using the t-test with $p \leq 0.05$. The rule for the acceptance or rejection of the hypothesis is that when p-value $>0.05$, the hypothesis is accepted but when $p$ value $\leq 0.05$, the hypothesis is rejected. The results are presented in Table 5 .

Table 5 shows that the $p$-values for the test of difference between the percentages of timeoverrun to initial contract period of projects in which in-sourced and outsourced project managers (0.847), architects $(0.563)$, quantity surveyors $(0.649)$, mechanical engineers $(0.360)$ and structural engineers $(0.209)$ were engaged are higher than the critical p-value $(0.05)$ therefore the hypothesis is accepted. These results imply that the time-overruns of projects in which in-sourced project managers, architects, quantity surveyors, mechanical and structural engineers were engaged are not significantly different from those of projects in which 
outsourced project managers, architects, quantity surveyors, mechanical and structural engineers were engaged. Similarly, the $p$-values for the test of difference between the percentages of cost-overrun to initial contract sum of projects in which in-sourced and outsourced project managers (0.937), electrical engineers (0.112) and structural engineers (0.733) were engaged are higher than the critical $p$-value (0.05). These results signify that the hypothesis is accepted that is the cost-overruns of projects in which in-sourced project managers, electrical and structural engineers were engaged are not significantly different from projects in which outsourced project managers, electrical and structural engineers were engaged.

\begin{tabular}{|c|c|c|c|c|c|c|c|c|}
\hline Parameter & Consultant & $\mathbf{N}$ & Mean & t-value & Df & p-value & Decision & Diff \\
\hline $\begin{array}{l}\text { Project manager } \\
\text { Time-overrun } \\
\text { Cost-overrun }\end{array}$ & $\begin{array}{l}\text { In-source } \\
\text { Outsource } \\
\text { In-source } \\
\text { Outsource }\end{array}$ & $\begin{array}{l}66 \\
14 \\
50 \\
14\end{array}$ & $\begin{array}{l}16.29 \\
17.01 \\
12.81 \\
13.35\end{array}$ & $\begin{array}{l}-0.194 \\
-0.080\end{array}$ & 62 & $\begin{array}{l}0.847 \\
0.937\end{array}$ & $\begin{array}{l}\text { Accept } \\
\text { Accept }\end{array}$ & $\begin{array}{l}\text { NS } \\
\text { NS }\end{array}$ \\
\hline $\begin{array}{l}\text { Architect } \\
\text { Time-overrun } \\
\text { Cost-overrun }\end{array}$ & $\begin{array}{l}\text { In-source } \\
\text { Outsource } \\
\text { In-source } \\
\text { Outsource }\end{array}$ & $\begin{array}{l}30 \\
48 \\
24 \\
28\end{array}$ & $\begin{array}{c}16.52 \\
14.95 \\
7.87 \\
16.00\end{array}$ & $\begin{array}{l}0.581 \\
-2.396\end{array}$ & $\begin{array}{l}76 \\
50\end{array}$ & $\begin{array}{l}0.563 \\
0.020\end{array}$ & $\begin{array}{l}\text { Accept } \\
\text { Reject }\end{array}$ & $\begin{array}{l}\text { NS } \\
\text { S }\end{array}$ \\
\hline $\begin{array}{l}\text { Quantity surveyor } \\
\text { Time-overrun } \\
\text { Cost-overrun }\end{array}$ & $\begin{array}{l}\text { In-source } \\
\text { Outsource } \\
\text { In-source } \\
\text { Outsource }\end{array}$ & $\begin{array}{l}38 \\
42 \\
32 \\
22\end{array}$ & $\begin{array}{c}15.74 \\
17.03 \\
8.09 \\
19.78\end{array}$ & $\begin{array}{l}-0.457 \\
-3.631\end{array}$ & 52 & $\begin{array}{l}0.649 \\
0.001\end{array}$ & $\begin{array}{l}\text { Accept } \\
\text { Reject }\end{array}$ & $\begin{array}{l}\text { NS } \\
\text { S }\end{array}$ \\
\hline $\begin{array}{l}\text { Mechanical engr } \\
\text { Time-overrun } \\
\text { Cost-overrun }\end{array}$ & $\begin{array}{l}\text { In-source } \\
\text { Outsource } \\
\text { In-source } \\
\text { Outsource }\end{array}$ & $\begin{array}{l}28 \\
52 \\
24 \\
30\end{array}$ & $\begin{array}{c}18.19 \\
15.47 \\
8.52 \\
16.32\end{array}$ & $\begin{array}{l}0.920 \\
-2.297\end{array}$ & $\begin{array}{l}78 \\
52\end{array}$ & $\begin{array}{l}0.360 \\
0.026\end{array}$ & $\begin{array}{l}\text { Accept } \\
\text { Reject }\end{array}$ & $\begin{array}{l}\text { NS } \\
\text { S }\end{array}$ \\
\hline $\begin{array}{l}\text { Electrical engr } \\
\text { Time-overrun } \\
\text { Cost-overrun }\end{array}$ & $\begin{array}{l}\text { In-source } \\
\text { Outsource } \\
\text { In-source } \\
\text { Outsource }\end{array}$ & $\begin{array}{l}32 \\
48 \\
28 \\
26\end{array}$ & $\begin{array}{l}19.84 \\
14.13 \\
10.16 \\
15.75\end{array}$ & $\begin{array}{r}2.025 \\
-1.618\end{array}$ & $\begin{array}{l}78 \\
52\end{array}$ & $\begin{array}{l}0.046 \\
0.112\end{array}$ & $\begin{array}{l}\text { Reject } \\
\text { Accept }\end{array}$ & $\begin{array}{l}\text { S } \\
\text { NS }\end{array}$ \\
\hline $\begin{array}{l}\text { Structural engr } \\
\text { Time-overrun } \\
\text { Cost-overrun }\end{array}$ & $\begin{array}{l}\text { In-source } \\
\text { Outsource } \\
\text { In-source } \\
\text { Outsource }\end{array}$ & $\begin{array}{l}44 \\
34 \\
38 \\
14\end{array}$ & $\begin{array}{l}18.07 \\
14.40 \\
13.67 \\
12.27\end{array}$ & $\begin{array}{l}1.266 \\
0.344\end{array}$ & $\begin{array}{l}76 \\
50\end{array}$ & $\begin{array}{l}0.209 \\
0.733\end{array}$ & $\begin{array}{l}\text { Accept } \\
\text { Accept }\end{array}$ & $\begin{array}{l}\text { NS } \\
\text { NS }\end{array}$ \\
\hline
\end{tabular}

Table 5 Results of t-test of difference in project performance based on the use of in-sourced and outsourced consultants

$\mathrm{N}=$ Number of respondents, Diff=Difference, engr=engineer

Idoro, G I (2011) 'Influence in-sourcing and outsourcing of consultants on construction project performance in Nigeria', Australasian Journal of Construction Economics and Building, 11 (4) 45-58 
Table 5 however shows that the p-value for the test of difference between the percentages of time-overrun to initial contract period of projects in which in-sourced and outsourced electrical engineers (0.046) were engaged is less than the critical p-value $(0.05)$ therefore the hypothesis is rejected. This result implies that the time-overrun of projects in which in-sourced electrical engineers were engaged are significantly different from that of projects in which outsourced electrical engineers were engaged. Similarly, the p-values for the test of difference between the percentages of cost-overrun to initial contract sum of projects in which in-sourced and outsourced architects (0.020), quantity surveyors (0.001) and mechanical engineers (0.026) were engaged are less than the critical p-value (0.05) therefore the hypothesis is rejected. These results indicate that the cost-overruns of projects in which outsourced architects, quantity surveyors and mechanical engineers were engaged are significantly different from projects in which in-sourced architects, quantity surveyors and mechanical engineers were engaged. The results in Table 5 reveal that the mean time-overrun of projects in which in-sourced electrical engineers were engaged (19.84 weeks) is higher than the mean time-overrun of projects in which outsourced electrical engineers were engaged (14.13 weeks). This result tends to indicate that less time-overrun was recorded in projects in which outsourced electrical engineers were engaged compared to projects in which their in-sourced counterparts were engaged. However, the mean cost-overrun of projects in which outsourced architects (N16 million), quantity surveyors (N19.78 million) and mechanical engineers (N16.32 million) were engaged are higher than the mean cost-overruns of projects in which in-sourced architects (N7.87 million), quantity surveyors (N8.09 million) and mechanical engineers (N8.52 million) were engaged. These results indicate that less cost-overrun was recorded in projects in which insourced architects, quantity surveyors and mechanical engineers were engaged compared to projects in which their outsourced counterparts were engaged.

\section{Discussion of Findings}

The analysis of the percentages of use of the two sources of consultants in Table 2 has shown that the extent of use of in-sourced project managers is the highest, followed by in-sourced quantity surveyors while the extent of use in-sourced electrical engineers is the least. The reverse is the case of the extent of use of outsourced consultants in project development. These results indicate that clients' preference for in-sourced and outsourced consultants in project development varies from one consultant to another, and that clients do not rely on one of the two sources of consultants in project development; rather they use their staff as some consultants and source the others from outside.

The results in Table 4 that there is no significant difference between the extent of use of insourced and outsourced consultants also support the finding that clients use the two types of consultants for the development of projects. This finding shows that the two types of consultants are important features of project development in Nigeria. It also goes to show that clients are found of employing professionals who serve as consultants in their organizations. The results of the influence of the use of the two types of consultants in Table 4 shows that the use of either in-sourced or outsourced consultants has significant influence on clients' assessment of project cost, quality, conflicts between project team members and cost-overruns.

The results of the test of difference in the performance of projects in which the two types of consultants were engaged tend to indicate that the engagement of in-sourced or outsourced project managers and structural engineers does not make any difference on project performance. This tends to imply that clients can engage their staff or external consultants as project managers and structural engineers without any increase or decrease in both time and cost overruns. However, the results of the study show that the engagement of outsourced electrical engineers could help to achieve savings in the delivery time of projects compared to

Idoro, G I (2011) 'Influence in-sourcing and outsourcing of consultants on construction project performance in Nigeria', Australasian Journal of Construction Economics and Building, 11 (4) 45-58 
when in-sourced electrical engineers are engaged but such will not make any difference in the overrun in the delivery cost of projects.

This result may suggest that an outsourced electrical engineer is unlikely to prolong his involvement in a project but more willing to perform his service and disengage from a project on time than his counterpart in the employment of the client. This interest can be attributed to the fact that his service fee is fixed and may not vary with the duration of his involvement in a project. The implication of this result is that considerable time can be saved in projects that have long duration when electrical engineers are outsourced. On the other hand, the engagement of in-sourced architects, quantity surveyors and mechanical engineers could help to achieve savings in the delivery cost of projects compared to when outsourced consultants are engaged but this will not make any difference in the delivery time of projects. This result may indicate that in-sourced architects, quantity surveyors and mechanical engineers have better knowledge of both the client and project requirements than their outsourced counterparts and this knowledge helps to minimise incidences of variations and the likes that are responsible for cost-overrun. The implication of this result is that cost can be saved when project design, in particular architectural and mechanical drawings and bills of quantities are carried out in-house, that is direct labour instead of contract.

\section{Conclusion}

The study has established that in-sourcing and outsourcing of consultants is a feature of the project delivery process. This finding shows that clients are often faced with the challenge of deciding which of the two types of consultants to engage when they embark on project development. Organisations all over the world are abandoning the practice of keeping many construction professionals as staff because construction is a service activity and they need to concentrate on their core business activities and reduce overhead costs. This study has contributed to existing studies on the benefits of in-sourcing and outsourcing by revealing the benefits derived from project outcome when they are adopted. It has revealed that organisations do not have anything to lose on project outcome by engaging external project managers and structural engineers as project consultants. Specifically, it has discovered that outsourcing electrical engineers in project development not only provide the clients with the numerous benefits of outsourcing discovered in previous studies, it will equally assist organisations to reduce the delay to be experienced in project delivery. On the other hand, the study has discovered that by engaging in-house architects, quantity surveyors and mechanical engineers as consultants, organisations are likely to derive the benefit of reduced cost-overrun. These results suggest the need for organisations to engage a mixture of in-sourced and outsourced consultants in project development. In adopting this, it is suggested that such organisations should give consideration to electrical engineers in outsourcing and architects, quantity surveyors and mechanical engineers in in-sourcing.

\section{Suggestion for Further Studies}

Time and cost overruns are not the only parameters of project outcome. The study could not investigate the benefits associated with other important parameters of project outcome such as project quality when the two consultants are engaged in project development. It therefore suggests further studies on the influence of the use of the two consultants on other parameters of project outcome such as project quality in order to complement the results of the study.

\section{References}

Bettis, R., Bradley, S. and Hamel, G. (1992) 'Outsourcing and industrial decline', Academy of Management Executive, 6 (1), 7-22 
Boes, H. and Doree, A. (2009) 'Public procurement of local authorities in the Netherlands: a case of breaking tradition for a more strategic approach, Proceedings of RICS COBRA Research Conference, University of Cape Town, 10-11th September

Carlson, B. (1989) 'Flexibility and theory of the organisation', International Journal of Industrial Organisation, 7 (1), 189-203

D'Aveni, R. and Ravenscraft, D. (1994) 'Economies of integration versus bureaucracy costs: Does vertical integration improve performance?', Academy of Management Journal, 37 (5), 1167-1206

Dess, G. G., Rasheed, A., McLaughlin, K. and Priem, R. (1995) 'The new corporate architecture', Academy of Management Executive, 9 (3), 7-20

Domberger, S. (1998) The contracting organisation: a strategic guide to outsourcing, $1^{\text {st }}$ edition, Oxford University Press, Oxford

Ender, K. L. and Mooney, K. A. (1994) 'From outsourcing to alliances: Strategies for sharing leadership and exploiting resources in metropolitan universities', Metropolitan Universities: An International Forum, 5 (3), 51-60

Federal Government of Nigeria (1986) Budget, Federal Government Press, Lagos

Gilley, K. T. and Rasheed, A. (2000) 'Making more by doing less: an analysis of outsourcing and its effect on firm performance', Journal of Management, 26 (4), 763-790

Grover, V, Cheon, M. J. and Teng, J. T. C. (1996) 'The effect of service quality and partnership on the outsourcing of information systems functions', Journal of Management Information Systems, 12 (4), 89-116

Harigan, K. R. (1985) 'Formulating vertical integration strategies', Academy of Management Review, 9 (4), 638-652

Harrigan, K. R. (1985) 'Exit barriers and vertical integration', Academy of Management Journal, 28 (3), 686-697

Harrison, B. T. (1994) Lean and Mean: The Changing Landscape of Corporate Power in the Age of Flexibility, Basic Books, New York

Havemann, G. (2007) 'The challenge of engaging South Africa's unemployed in construction sector delivery', Proceeding of the CIB World Building Conference on Construction for Development, Cape Town, South Africa, 14-18 May 2007

Idoro, G. I. (2004) 'The effect of globalisation on safety in the construction industry in Nigeria', Proceedings of International Symposium on Globalisation and Construction, 17-18 November, Asian Institute of Technology, Thailand, 817-826

Idoro, G. I. (2006) 'An evaluation of the use of direct labour system in the Nigerian construction Industry', Urban and Planning Review, 1 (1), 75-88

Idoro, G. I. (2009a) 'Clients' perception of construction project leaders in the Nigerian construction Industry', Journal of Engineering, Design and Technology, 7 (3), 264-271

Idoro, G. I. (2009b) 'Correlation between managerial and technical capacities and quality performance of indigenous and expatriate contractors in Nigeria', International Journal of Construction Project Management, 1 (2), 173-187

Idoro, G. I. (2010) 'Influence of quality performance on clients' patronage of indigenous and expatriate construction contractors in Nigeria', Journal of Civil Engineering and Management, 16 (1), 65-73 
Idoro, G. I. and Okun, B. O. (2011) 'Project leaders' assessment of the contribution of contractors to delay in the delivery of federal government projects in Nigeria', Proceedings of RICS COBRA 2011 International Built and Human Environment Conference, 12-13 September, University of Salford, Manchester, UK

Kanji, G. K. and Wong, A. (1998) 'Total quality culture in the construction industry', Total Quality Management, 9 (4/5), 133-140

Kotabe, M. (1992) Global Sourcing Strategy: R\&D, Manufacturing and Marketing Interfaces, $1^{\text {st }}$ edition, Quorum Publications, New York

Kotabe, M. and Murray, J. (1990) 'Linking product and process innovations and modes of international sourcing in global competition: a case of foreign multinational firms', Journal of International Business Studies, 3, 383-408

Lei, D. and Hitt, M. (1995) 'Strategies restructuring and outsourcing: The effect of mergers and acquisition and LBOs on building firm skills and capabilities', Journal of Management, 21 (5), 835-859

Loh, L. and Venkatraman, N. (1992) 'Determinants of information technology outsourcing: a cross-sectional analysis', Journal of Management Information Systems, 9 (1), 7-24

Meiling, J. and Johnsson, H. (2009) 'Feedback in industrialised housing: why does it not happen?', Proceedings of RICS COBRA Research Conference, University of Cape Town, 1011th September

Michell, K., Brown, P., Catell, K., Edwards, P. and Pearl, R. (2007) 'Stakeholder perception of construction time, cost and quality management of building projects', Proceeding of the CIB World Building Congress on Construction for Development, Cape Town, South Africa, 14-18 May 2007

Odusami, K. T. (1999) 'A survey of current trends in quantity surveying consultancy practice in Nigeria', The Quantity Surveyor, Journal of the Nigerian Quantity Surveyor, Jan/March, 57-62

Quinn, J. B. (1992) Intelligent Enterprise: A Knowledge and Service Based Paradigm for Industry. Free Press, New York

Quinn, J. B., Doorley, T. L. and Paquette, P. C. (1990) 'Technology in services: rethinking strategic focus', Sloan Management Review, 31 (2), 79-87

Renier, B. and Volker, L. (2009) 'The architect as a system integrator', Proceedings of RICS COBRA Research Conference, University of Cape Town, 10-11th September, 103-113

Sang, J. K. (2010) 'Outsourcing in Kenyan universities: an examination of challenges and opportunities', International Journal of Business and Social Science, 1 (2), 204-212

Sattineni, A. and University, A. (2008) 'Outsourcing and off-shoring: options for the US construction industry', International Business and Economics Research Journal, 7 (5), 59-66

Teece, D (1987) 'Capturing value from technological innovation, strategic partnering and licensing decisions in Guile, B. and Brooks, H. (Eds), Technology and Global Industry, National Academy Press, Washington

Tembo, E. and Rwelamila, P. M. D. (2007) 'Project management maturity in public sector organisations: the case of Botswana', Proceedings of CIB Conference W065/055: Commissions Transformation through Construction organised by Herriot-Watt, University, Edinburg, Dubai, November 